\title{
Citlivostní analýza vybraných vstupních parametrů numerického modelu HEC-RAS při hydraulických výpočtech proudění vody v korytech toků a záplavových územích
}

\section{DAVID DUCHAN, STANISLAV KOTAŠKA, ŠIMON POSPÍŠILÍK, ALEŠ DRÁB}

Klíčová slova: citlivostní analýza - hydraulický výpočet - 2D numerický model - HEC-RAS - turbulentní model - záplavové území

\section{SOUHRN}

Hydraulické výpočty proudění vody v korytech vodních toků a záplavových územích se $v$ současné inženýrské praxi provádějí primárně s použitím $1 D, 2 D$ a spřažených 1D/2D numerických modelů. Matematický model je v prípadě zmiňované 2D schematizace obvykle založen na tzv. rovnicích proudění v mělkém proudu (shallow water equations), přičemž k matematickému popisu turbulentního proudění se zde využívají tzv. turbulentní modely s různým pojetím modelování turbulence. $V$ našich podmínkách je pro účely hydraulických výpočtů poměrně rož̌irirené programové vybavení HEC-RAS, které využívá turbulentního modelu založeného na Boussinesqově aproximaci. Cílem příspěvku je prezentace postupů a závěrů citlivostní analýzy, jež zohledňuje vliv vstupních parametrů uvedeného turbulentního modelu na výsledky hydraulických výpočtů $v$ prípadě použití $2 D$, respektive spřaženého 1D/2D modelu. Součástí analýz je rovněž ověření možného ovlivnění výsledků změnami dalších parametrů výpočtu, mezi které patří např. zavedení zjednodušeného řešení rovnic proudění v mělkém proudu aproximací difuzní vinou nebo způsob prostorové diskretizace řešené náhradní oblasti. K ověrovacím výpočtům byl vybrán jednak fiktivní úsek prizmatického koryta lichoběžníkového průřezu a dále reálný úsek koryta toku Svratka na území města Brna v délce cca 2,6 km. Účelem předkládaného příspěvku je především poskytnout potenciálním uživatelům $2 D$ numerických modelů, založených na rovnicích mělkého proudu, základní představu o nejistotách ve výsledcích hydraulických výpočtů, vyplývajících z volby vybraných vstupních parametrů.

\section{ÚVOD}

Pro účely hydraulických výpočtů proudění vody v korytech toků a záplavových územích se $v$ současnosti v inženýrské praxi využívají primárně $1 D, 2 D$ a spřažené 1D/2D numerické modely. Uvedený typ hydraulických výpočtů zpravidla představuje časově - a tedy i finančně - náročnou proceduru, která je zatížena řadou nejistot. Jako jeden z podstatných zdrojů nejistot Ize označit volbu vhodného hydrodynamického modelu k provedení hydraulických výpočtů a s tím související způsob schematizace řešené oblasti. Volba dimenze modelu spolu s dalšími vstupními parametry může mít podstatný vliv na výsledky výpočtů. Zatímco 2D modely vycházejí z předpokladu dvourozměrného (2D) proudění vody na celé řešené náhradní oblasti, spřažené 1D/2D modely uvažují v dílčích částech řešené oblasti s jednorozměrným (1D) prístupem [2-9]. Obvyklá je schematizace samotného vodního toku v rozsahu břehových hran pomocí 1D modelu a prilehlého záplavového území $2 \mathrm{D}$ modelem. Hlavním prínosem použití spřažených $1 \mathrm{D} / 2 \mathrm{D}$ modelů je zejména snadnější hydraulické řešení objektů v zájmové oblasti (např. mosty, propustky, jezy) a dále menší nároky na podklady zachycující morfologii koryta řešených vodních toků. $V$ prípadě 1D modelu Ize koryto toku schematizovat soustavou prríčných řezů, zatímco pro 2D model je nezbytné zajistit kompletní digitální model reliéfu koryta toku. Nevýhodou použití spřažených 1D/2D modelů oproti 2D modelům mohou být např. přijatá zjednodušení hydraulických jevů v místech propojení mezi 1D a 2D oblastmi a možná větší časová náročnost prováděných výpočtů. Obecně je problematice srovnání 1D, 2D a 1D/2D hydrodynamických modelů věnována rada publikací, viz např. [10-17].

Zmiňované 2D numerické modely jsou obvykle založeny na matematickém modelu zahrnujícím tzv. rovnice proudění v mělkém proudu (shallow water equations) [18], jež v různé míře umožňují rovněž zohlednění turbulence. K matematickému popisu turbulentního proudění se využívají tzv. turbulentní modely s různým pojetím modelování turbulence [1]. V našich podmínkách je pro účely hydraulických výpočtů poměrně rozšiřrené programové vybavení HEC-RAS, které v rámci 2D schematizace využívá turbulentního modelu založeného na Boussinesqově aproximaci [18]. Jeho podstatou je zavedení tzv. turbulentní viskozity. Pro její výpočet je však nezbytná specifikace bezrozměrného koeficientu, jenž je závislý na charakteru proudění a může nabývat hodnot v poměrně širokém rozpětí [18-20].

Cílem príspěvku je prezentace výsledků citlivostní analýzy zohledňující vliv uvedeného vstupního parametru turbulentního modelu na výsledky hydraulických výpočtů v prípadě použití 2D schematizace, respektive při použití Tab. 1. Hodnoty bezrozměrného koeficientu D pro výpočet turbulentní viskozity dle [18]
Tab. 1. Values of eddie viscosity transverse mixing coefficient D [18]

D Geometrie koryta, druh povrchu

\begin{tabular}{ll}
\hline 0,11 až 0,26 & Rovné koryto, hladký povrch \\
\hline 0,3 až 0,77 & Mírné meandry, střední nerovnosti povrchu \\
\hline 2,0 až 5,0 & Výrazné meandry, hrubý povrch
\end{tabular}


spřaženého 1D/2D modelu. Součástí analýz je rovněž ověření možného ovlivnění výsledků změnami dalších parametrů výpočtu, mezi něž patří např. zavedení zjednodušeného řešení rovnic proudění v mělkém proudu aproximací difuzní vinou nebo způsob prostorové diskretizace řešené náhradní oblasti. K ověřovacím výpočtům byl vybrán jednak fiktivní úsek prizmatického koryta lichoběžníkového průřezu a dále reálný úsek koryta toku Svratka na území města Brna v délce cca 2,6 km. Předkládaný príspěvek si neklade za cíl detailní teoretický rozbor daného problému. Jeho účelem je především poskytnout uživatelům 2D numerických modelů, založených na rovnicích mělkého proudu, základní představu o nejistotách ve výsledcích hydraulických výpočtů vyplývajících z volby vybraných vstupních parametrů.

\section{METODA CITLIVOSTNÍ ANALÝZY}

Citlivostní analýza vlivu bezrozměrného koeficientu pro výpočet turbulentní viskozity na výsledky hydraulických výpočtů proudění vody v korytech toků a záplavových územích spočívá v realizaci a následné analýze řady variantních výpočtů s použitím 2D, respektive spřaženého 1D/2D numerického modelu. Pro tyto účely bylo zvoleno poměrně rozšiřené programové vybavení HECRAS, které je založeno na matematickém modelu dvourozměrného (2D) proudění kapaliny o malé hloubce s volnou hladinou, tj. na tzv. rovnicích proudění $\checkmark$ mělkém proudu (FM). Matematický model dále umožňuje výpočty s použitím zjednodušené formy rovnic mělkého proudu bez použití turbulentního modelu, označované jako aproximace difuzní vlnou (DW). Pro srovnání byl rovněž využit matematický model s jednorozměrnou (1D) schematizací. Podrobný teoretický popis zmiňovaných matematických modelů Ize nalézt např. v literatuře [18]. Konkrétní uživatelské nastavení parametrů v programu HEC-RAS Ize provést s použitím příručky [22] (viz klíčová slova "Eddy Viscosity Transverse Mixing Coefficient", "Full Momentum Equation" a "Diffusion Wave").

Jednotlivé řešené varianty se $v$ rámci citlivostní analýzy lišily použitím rưzných hodnot bezrozměrného koeficientu $D$, nezbytného pro výpočet turbulentní viskozity, která je podstatou turbulentního modelu využívajícího Boussinesqovu aproximaci. Sledovanou veličinou byla ve všech prípadech vypočtená úroveň hladiny v ose rešených koryt toků. Zmiňovanou turbulentní (tzv. „eddy“) viskozitu $v_{t^{\prime}}$ vstupující do řešení rovnic proudění v mělkém proudu (FM), Ize vyjádřit vztahem [18]:

$$
v_{t}=D h u_{*}
$$

kde $D$ je bezrozměrný koeficient pro výpočet turbulentní viskozity a $u_{*}$ smyková rychlost definovaná jako:

$$
u_{*}=\sqrt{g R S}=\frac{\sqrt{g}}{C}|V|=\frac{n \sqrt{g}}{R^{\frac{1}{6}}}|V|
$$

kde $R$ je hydraulický poloměr, $g$ tíhové zrychlení, $S$ sklon čáry energie, C Chézyho rychlostní součinitel, |V| střední svislicová rychlost a n Manningưv drsnostní součinitel. Pro hydraulické výpočty v programu HEC-RAS udává Brunner [18] orientační rozsahy hodnot bezrozměrného koeficientu $D$ pro výpočet turbulentní viskozity uvedené v tab. 1.

Citlivostní analýza byla provedena na dvou typech modelů, které jsou v dalším textu označeny písmeny A, B. Model A byl koncipován s ohledem na eliminaci dalších možných vlivů na výsledky výpočtů (nerovnoměrnost rychlostního pole, náhlé kontrakce při změnách tvaru príčných profilů apod.). Z tohoto důvodu bylo pro citlivostní analýzu zvoleno prizmatické koryto lichoběžníkového průřezu, jehož hlavní parametry jsou patrné z obr. 1 a tab. 2. Pro účely simulace odlehčování části průtoku do inundačního území bylo do modelu A začleněno rovněž pravobřežní lokální snížení břehové hrany o 0,3 m $\checkmark$ délce 100 m, nacházející se uprostřed délky řešeného úseku koryta (viz obr. 1 a 6). Za takto vytvořenou přelivnou hranou byl zaveden předpoklad volného odtoku vody.

\section{Tab. 2. Model A - základni parametry koryta}

Tab. 2. Model A - river reach basic parameters

\section{Parametr, jednotky \\ Hodnota}

\begin{tabular}{ll}
\hline Podélný sklon dna koryta $i[-]$ & 0,002 \\
\hline Délka koryta $L[\mathrm{~m}]$ & 500 \\
\hline Drsnostní součinitel dle Manninga $n[-]$ & 0,035 \\
\hline Průtok Q [m³/s] & 17,96 \\
\hline $\begin{array}{l}\text { Dolní okrajová podmínka - hloubka } \\
\text { vody } h_{d}[\mathrm{~m}]\end{array}$ & $1,5 \mathrm{~m}$ (viz varianty A.1, A.2, A.3), \\
\end{tabular}

Pro výše popsaný model A byla následně provedena citlivostní analýza spočívající ve variantních výpočtech A.1 až A.4. Nastavení jednotlivých variant (viz tab. 3) bylo voleno tak, aby byl vždy jeden z testovaných vstupních parametrů modelu zadán jako konstantní a druhý s proměnlivými hodnotami (viz sloupce výpočetní sít a koeficient turbulence $D v$ tab. 3). Zároveň ve všech řešených variantách proběhlo ověření vlivu použitého matematického modelu (viz sloupec model). Výsledky 1D modelu byly určeny pouze k orientačnímu srovnání s 2 D modely a nebyly předmětem citlivostní analýzy. Zvolená velikost elementů

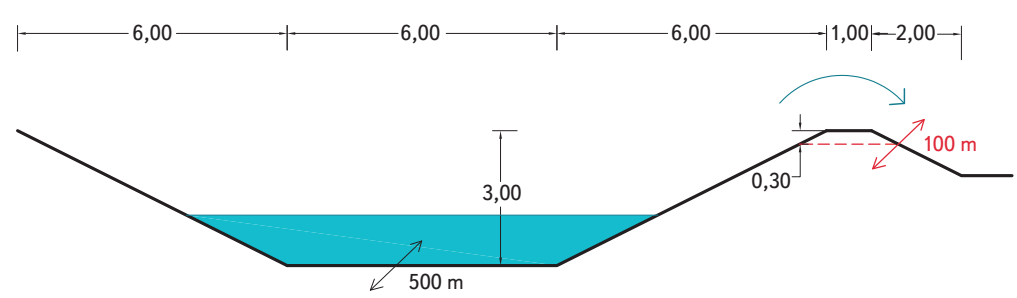

Obr. 1. Model A - prŕčný profil koryta toku (přeliv je ve funkci pouze u varianty A.4 dle tab. 3) Fig. 1. Model A - river reach cross section (the overflow is functional only for variant A.4 according to tab. 3)

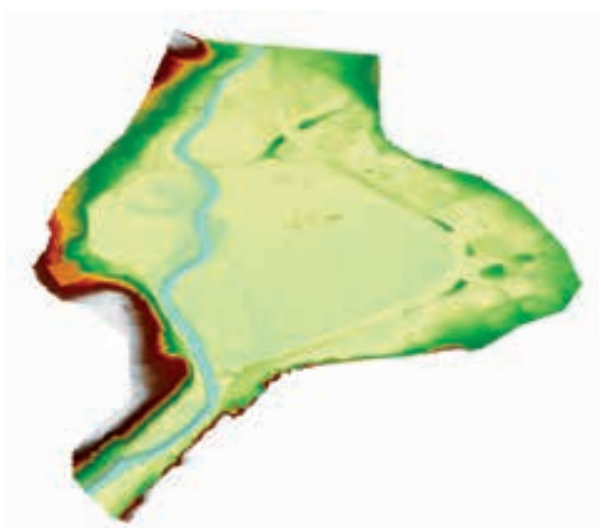

Obr. 2. Situace modelu řeky Svratky v úseku km 50,2 až km 52,8

Fig. 2. Situation of the Svratka river model in the section of $\mathrm{km} 50.2$ to $\mathrm{km} 52.8$ 
Tab. 3. Model A - základní parametry rešených variant výpočtů

Tab. 3. Model A - basic parameters of solved calculation variants

\section{Varianta Model Výpočetní sít}

Koeficient turbulence $D$

pro model 2D (FM)

Poznámka

\section{A.1}

1D, 2D (DW),

Ortogonální ve variantách s různou velikostí elementů 2D (FM) (18 $m ; 6 m ; 1 m ; 0,5 m ; 0,25 m)$

0

1D, 2D (DW),
2D (FM)

Ortogonální s konstantní velikostí elementů 1 m

Ve variantách s různými hodnotami $D=0 ; 0,1 ; 0,2 ; 0,3 ; 0,4 ; 0,7$

\section{A.2}

1D, 2D (FM)

Ortogonální ve variantách s různou velikostí elementů (18 m; $6 \mathrm{~m} ; 3 \mathrm{~m} ; 1 \mathrm{~m} ; 0,5 \mathrm{~m})$

0,3

$\begin{array}{ll}\text { A.4 } & 1 \mathrm{D}, 2 \mathrm{D}(\mathrm{DW}), \\ & 2 \mathrm{D}(\mathrm{FM})\end{array}$

Ortogonální s konstantní velikostí elementů $1 \mathrm{~m}$ Ve variantách s různými hodnotami
$D=0 ; 0,3$

S pravobřežním přelivem

Tab. 4. Součinitelé drsnosti povrchu n dle Manninga pro model B

Tab. 4. Manning roughness coefficients $n$ for model $B$

\section{Druh povrchu}

\section{Součinitel drsnosti $n$ dle Manninga}

\begin{tabular}{ll}
\hline Dno vodního toku & 0,035 \\
\hline Břehy koryta s porostem & 0,045 \\
\hline Budovy & 1 \\
\hline
\end{tabular}

Zpevněné plochy
(cesty zpevněné, parkoviště, silnice)

\begin{tabular}{ll}
\hline Les & 0,12 \\
\hline
\end{tabular}

Zahrady, louky

0,1

výpočetní sítě odpovídala rozměrům koryta v příčném profilu dle obr. 1. Rozměr elementů $18 \mathrm{~m}$ postihoval celou šírku koryta, rozměr 6 m odpovídal dělení profilu na svahy a dno, rozměry elementů $1 \mathrm{~m}, 0,5 \mathrm{~m}$ a 0,25 m sloužily k ověření vlivu jemnějšího dělení oblasti.

Model B zachycuje reálný úsek vodního toku Svratky (viz obr. 2) cca mezi km 50,2 (jez Kamenný mlýn) až km 52,8 (jez Komín). Pro řešenou lokalitu byl připraven digitální model terénu sestavený na základě dat z digitálního modelu reliéfu 5. generace (DMR 5G) [21] a ze sonarového zaměření dna koryta toku Svratka. Dále bylo provedeno dílčí geodetické zaměření vybraných terénních hran metodou GPS - RTK (např. břehové hrany, zemní tělesa komunikací apod.). Rozložení drsností povrchu v zájmovém území bylo stanoveno odborným odhadem na základě místních šetření a mapových podkladů ZABAGED [21]. Konkrétní použité hodnoty součinitelů drsností $n$ dle Manninga jsou uvedeny v tab. 4.
Samotné sestavení modelu v programu HEC-RAS proběhlo s použitím aplikace RAS Mapper. Do modelu proudění byl připojen digitální model terénu a vrstva drsností povrchu. Pro zadanou oblast modelu proudění byly doplněny významné linie (břehové linie, terénní zlomy, príčné objekty v korytě). Výpočetní sít rešené náhradní oblasti byla tvořena elementy ve tvaru hexagonu s rozměry cca $8 \times 8$ m a s lokálním zjemněním v okolí významných linií. Hexagonální elementy umožňují, oproti čtvercovým elementům použitým v případě modelu A, snadnější tvorbu výpočtových sítí s nepravidelnými hranicemi náhradních oblastí, popř. s požadavky lokální změny velikostí elementů. Výpočetní sít sestávala z celkového počtu 80200 elementů. Dolní okrajová podmínka byla zadána měrnou křivkou jezu Kamenný mlýn ve staničení km 50,2, horní okrajová podmínka byla zadána hodnotou průtoku (viz tab. 5). Vytvořený $2 \mathrm{D}$ model byl následně upraven dle jednotlivých rešených variant výpočtu (viz tab. 5), tj. byly zadávány rưzné hodnoty bezrozměrného koeficientu $D$ pro výpočet turbulentní viskozity, použita aproximace difuzní vlnou apod.

Za účelem srovnání výsledků výpočtů byl vytvořen rovněž 1D numerický model koryta toku Svratka v zájmovém úseku tak, aby s maximální mírou respektoval parametry 2D modelu. $V$ prípadě $1 \mathrm{D}$ modelu byla provedena schematizace geometrie koryta toku zadáním osy a príčných řezů ve vzdálenostech $10 \mathrm{~m}$.

Citlivostní analýza byla provedena nad výsledky výpočtů ve variantách B.1 a B.2 s parametry uvedenými v tab. 5 . Ve variantě B.1 byla zvolena hodnota kulminačního průtoku $Q_{5}$ který přibližně odpovídal kapacitě rešeného úseku koryta. Při průtoku $Q_{20^{\prime}}$ použitém ve variantě B.2, již docházelo v malém rozsahu k rozlivům do přilehlého území. Takto vzniklá inundační území však nebyla průtočná a případné změny průtoku podél zájmového úseku toku Ize považovat za zanedbatelné.

Tab. 5. Model B - základní parametry rešených variant výpočtů

Tab. 5. Model B - basic parameters of solved calculation variants

\section{Varianta Model Výpočetní sít'}

\begin{tabular}{ll}
\hline B.1 & 1D, 2D (DW), Hexagonální s proměnlivou velikostí elementů \\
& $2 \mathrm{D}(\mathrm{FM})$
\end{tabular}

B.2

$1 \mathrm{D}, 2 \mathrm{D}(\mathrm{DW})$, $2 \mathrm{D}(\mathrm{FM})$

Hexagonální s proměnlivou velikostí elementů

\section{Koeficient turbulence $D$ pro model 2D (FM)}

Ve variantách s různými hodnotami

$D=0 ; 0,25 ; 0,50 ; 1,00 ; 1,50 ; 2,00$

Ve variantách s různými hodnotami

$D=0 ; 0,3$
Kulminační průtok

$Q_{5}=115 \mathrm{~m}^{3} / \mathrm{s}$

$Q_{20}=185 \mathrm{~m}^{3} / \mathrm{s}$ 


\section{VÝSLEDKY CITLIVOSTNÍ ANALÝZY}

Výsledky řešených variant A.1 až A.4 pro model A, prizmatického lichoběžníkového koryta, jsou patrné z obr. 3 až 6 . $V$ prípadě citlivostní analýzy vlivu prostorové diskretizace bez zohlednění turbulence (viz varianta A.1 na obr.3) je patrné, že za predpokladu shodné velikosti elementů výpočetní sítě jsou rozdíly mezi modely 2D (FM) a 2D (DW) minimální. V porovnání s 1D modelem narůstají rozdíly ve vypočtených hloubkách vody se zmenšující se velikostí výpočtových elementů. Jako hraniční je možné označit rozměr elementu cca 1 m, od kterého má již další zjemňování výpočetní sítě nepatrný vliv.

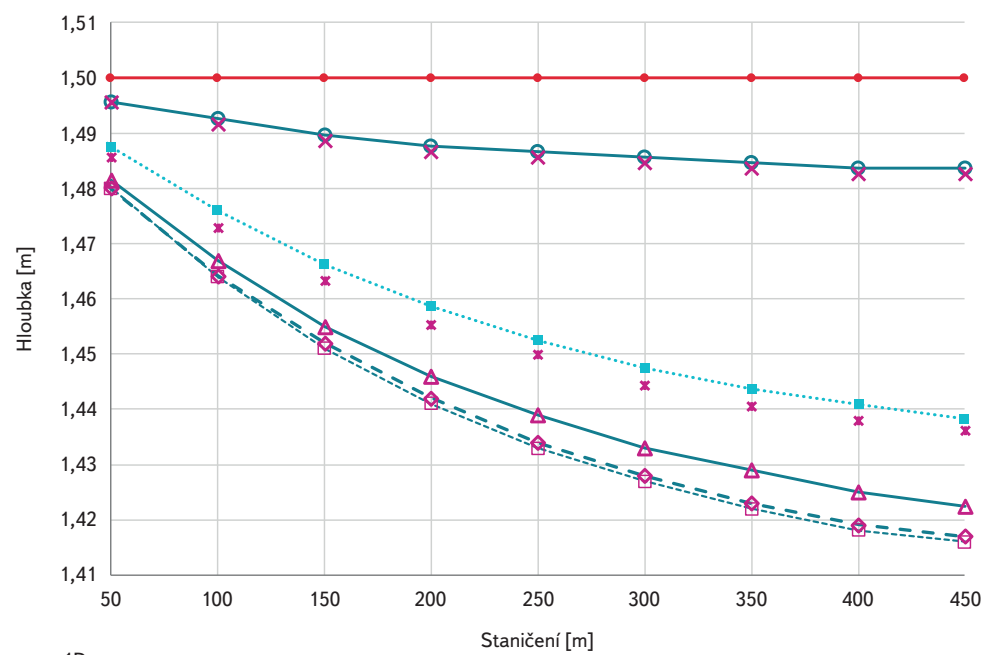

$\rightarrow 1 \mathrm{D}$

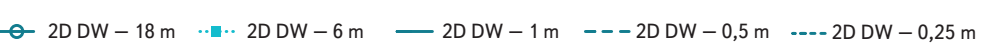

$\times 2 \mathrm{DFM}-18 \mathrm{~m} \quad 2 \mathrm{DFM}-6 \mathrm{~m} \quad \triangle 2 \mathrm{DFM}-1 \mathrm{~m} \quad \diamond 2 \mathrm{DFM}-0,5 \mathrm{~m} \quad \square 2 \mathrm{DFM}-0,25 \mathrm{~m}$

Obr. 3. Varianta A.1 - výsledky citlivostní analýzy vlivu prostorové diskretizace bez zohlednění turbulence (model 2D DW nebo 2D FM S D = 0)

Fig. 3. Variant A.1 - results of sensitivity analysis of the influence of spatial discretization without taking into account turbulence (model 2D DW or 2D FM with $D=0$ )

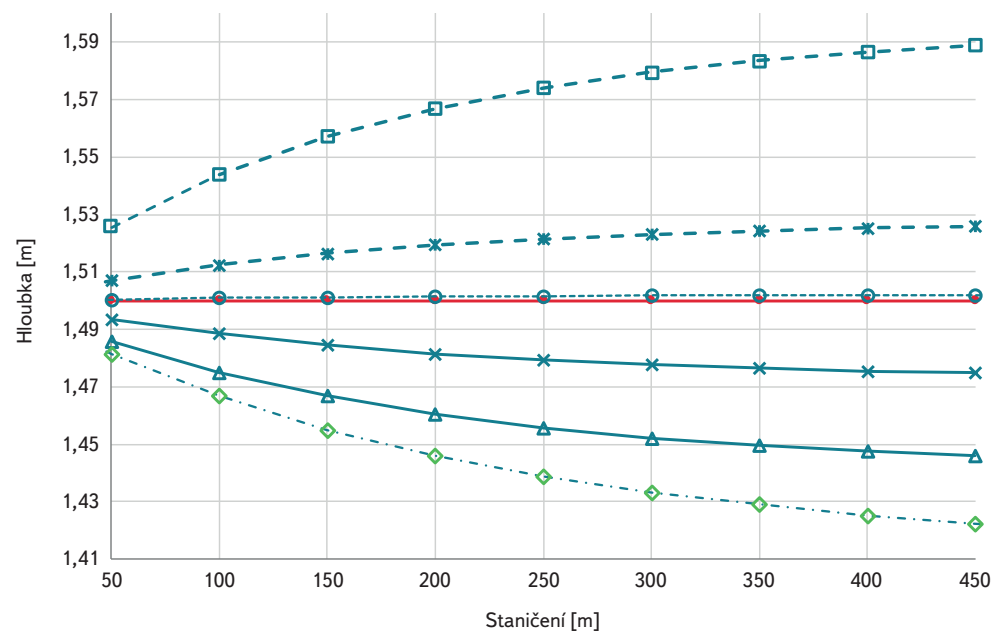

$\rightarrow 1 \mathrm{D} \diamond 2 \mathrm{DDW} \quad--2 \mathrm{DFMD}=0 \quad \longrightarrow 2 \mathrm{DFMD}=0,1 \quad$-2DFMD $=0,2$

-0. $2 D F M D=0,3 \quad-2 D$ FM D $=0,4 \quad \square-2 D F M D=0,7$

Obr. 4. Varianta A.2 - výsledky citlivostní analýzy vlivu parametrů turbulentního modelu (konstantní velikost elementů $1 \mathrm{~m}$ )

Fig. 4. Variant A.2 - results of sensitivity analysis of the influence of turbulence model parameters (constant size of elements $1 \mathrm{~m}$ )
Z výsledků citlivostní analýzy vlivu parametru turbulence při konstantních rozměrech výpočtové sítě s velikostí elementu $1 \mathrm{~m}$ (viz varianta A.2 na obr. 4) je patrné, že výsledkům 1D modelu se nejvíce blíži hloubky vody vypočtené pomocí modelu 2D (FM) s koeficientem $D=0,30$. Zjištěná hodnota $D=0,30$ je na hranici doporučovaného rozpětí hodnot dle tab. 1 pro zvolený typ prímého prizmatického koryta. Z obr. 4 je rovněž jasně patrný logický trend zvyšování úrovně hladiny, resp. hloubek vody v souvislosti s nárůstem hodnoty koeficientu D. Dolní obálku zjištěných hloubek vody naopak predstavují výsledky modelů $2 D(F M) s D=0$ a 2D (DW), tj. bez zohlednění vlivu turbulence.

Citlivostní analýza vlivu zvolené prostorové diskretizace při uvažování konstantního koeficientu $D=0,30$ (viz varianta A.3 na obr. 5) prokázala, že zvolená velikost elementů výpočetní sítě má při konstantní hodnotě koeficient $D=0,30$

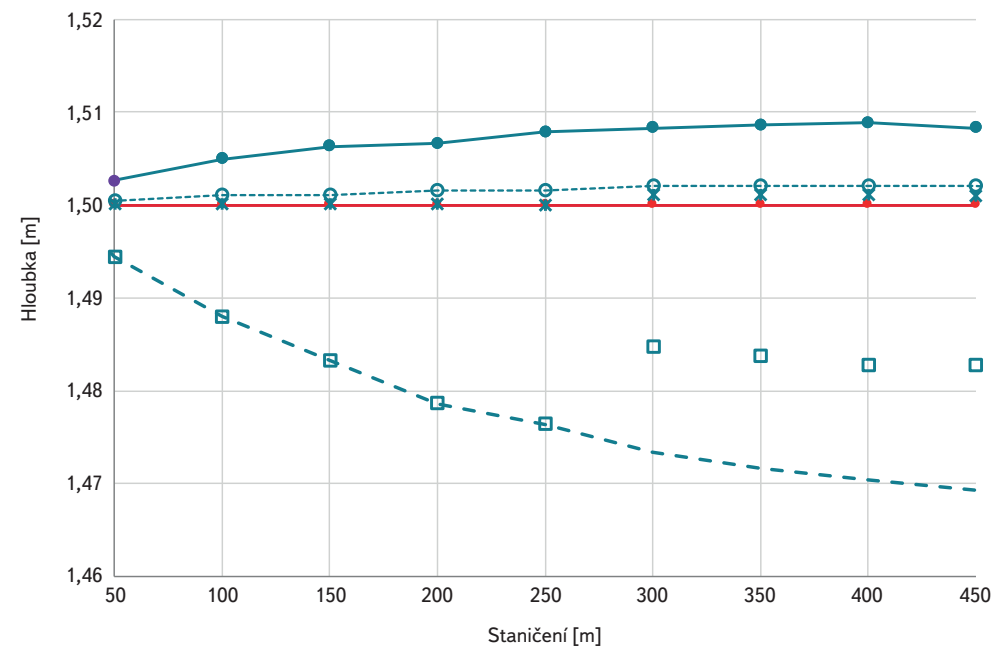

$\rightarrow 1 \mathrm{D}-0-2 \mathrm{DFM}-1 \mathrm{~m} \times 2 \mathrm{DFM}-0,5 \mathrm{~m} \rightarrow 2 \mathrm{DFM}-3 \mathrm{~m} \quad-2 \mathrm{DFM}-6 \mathrm{~m} \quad 2 \mathrm{DFM}-18 \mathrm{~m}$

Obr. 5. Varianta A.3 - výsledky citlivostní analýzy vlivu volby prostorové diskretizace při konstantních parametrech turbulentního modelu $(D=0,3)$

Fig. 5. Variant A.3 - results of sensitivity analysis of the influence of the choice of spatia discretization at constant parameters of the turbulence model $(D=0,3)$

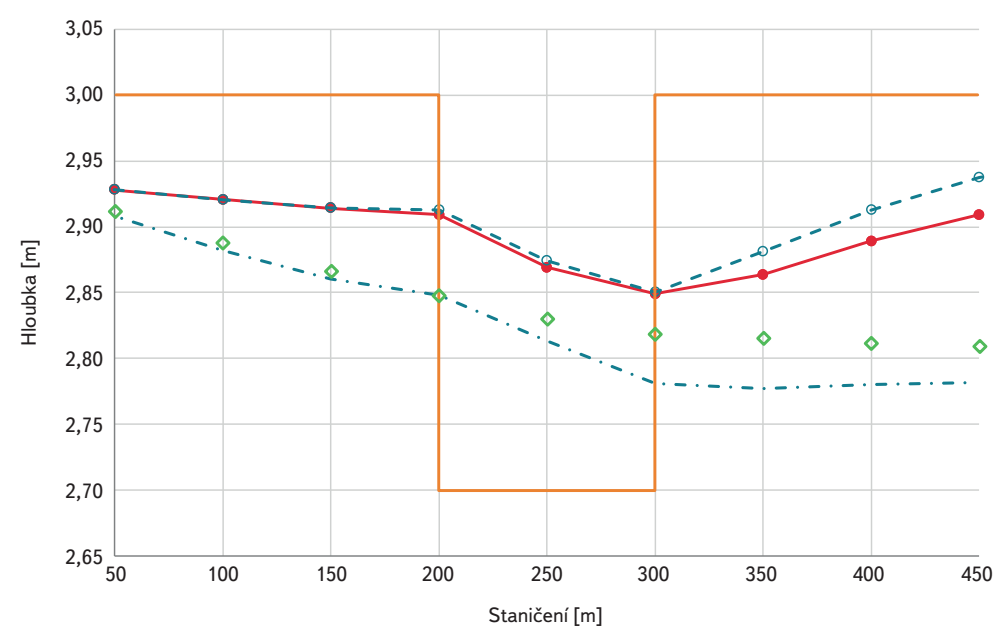

$\rightarrow 1 \mathrm{D} \quad \diamond 2 \mathrm{DDW} \quad--2 \mathrm{DFMD}=0 \quad-0-2 \mathrm{DFMD}=0,3 \quad$ - Pravý břeh s prélivem

Obr. 6. Varianta A.4 - výsledky citlivostní analýzy vlivu parametrů turbulentního modelu při bočním odlehčení průtoků z koryta (konstantní velikost elementů $1 \mathrm{~m}$ )

Fig. 6. Variant A.4 - results of sensitivity analysis of the influence of turbulence model parameters during lateral overflow from the river reach (constant size of elements $1 \mathrm{~m}$ ) 
vliv na vypočtené úrovně hladin. Odchylky v tomto prípadě narůstají se zvětšující se velikostí elementu. Jako hraniční lze, obdobně jako ve variantě A.1, označit velikost elementu cca $1 \mathrm{~m}$.

Výsledky ve variantě A.4 na obr. 6 s pravobřežním odlehčením průtoku potvrzují skutečnosti zjištěné v předchozích variantách A.1 až A.3. Oproti variantám bez odlehčení je zde patrné ovlivnění úrovní hladin v úseku nad přelivem.

Výsledky ve variantách B.1 a B.2, provedené na reálném úseku koryta, v zásadě potvrzují základní skutečnosti zjištěné ve variantách A.1 až A.4 pro fiktivní prizmatické koryto. Z obr. 7 a 8 je patrný nezanedbatelný vliv bezrozměrného koeficientu $D$ na úroveň hladiny při výpočtech s použitím modelu 2D (FM), tj. nárůst úrovně hladiny v souvislosti se zvyšováním hodnoty koeficientu D. Při vzájemném srovnání výsledků 2D (FM) a 1D modelu jsou oproti prizmatickému korytu (viz model A) patrné výrazně vyšší úrovně vypočtených hladin, a to i v př́padě

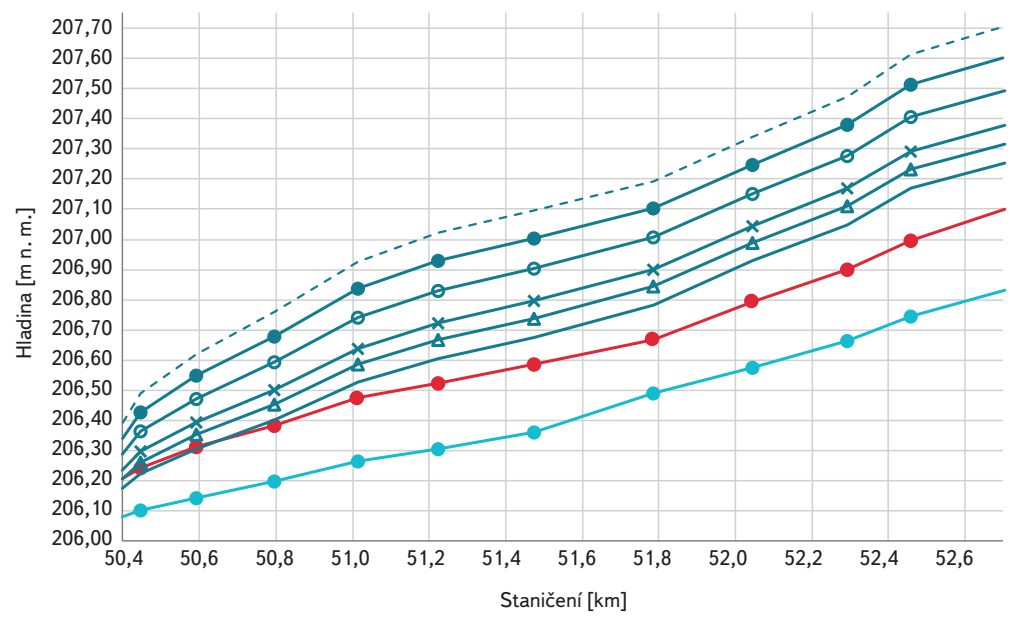

$\rightarrow 1 \mathrm{D} \rightarrow 2 \mathrm{D} \mathrm{DW} \longrightarrow 2 \mathrm{DFMD}=0 \multimap 2 \mathrm{DFMD}=0,25 \quad$ - $2 \mathrm{DFMD}=0,50$

$\multimap 2 \mathrm{DFMD}=1,00 \multimap 2 \mathrm{DFMD}=1,50 \quad-2 \mathrm{DFMD}=2,00$

Obr. 7. Varianta B.1 - výsledky citlivostní analýzy vlivu bezrozměrného koeficientu D na úroveň hladiny prí průtoku $Q_{\text {, }}$

Fig. 7. Variant B.1 - results of sensitivity analysis of the influence of dimensionless coefficient $D$ on the water level at discharge $Q$

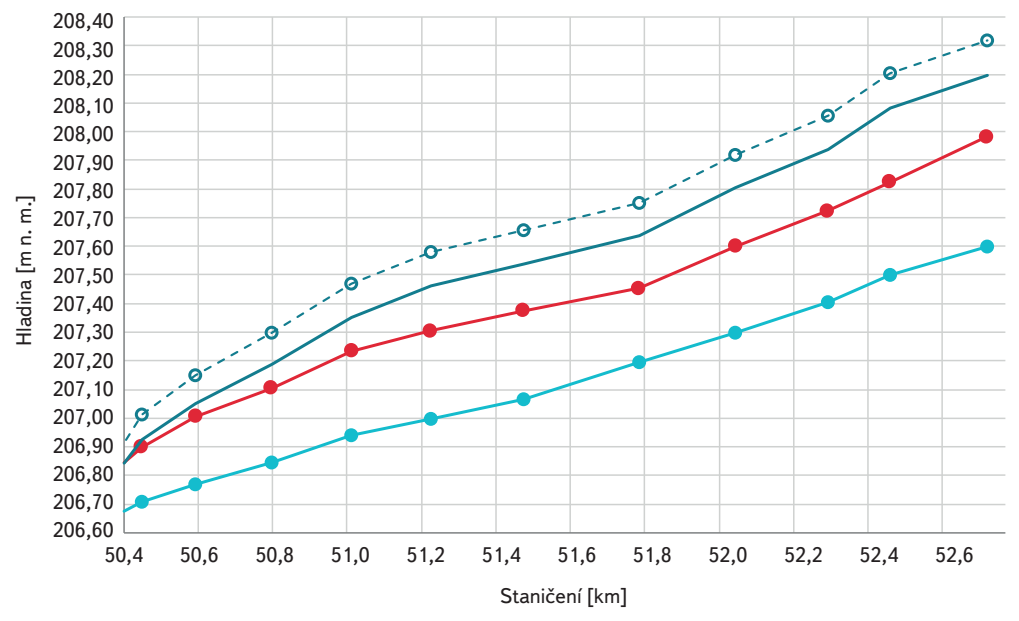

$\rightarrow 1 \mathrm{D} \quad \rightarrow 2 \mathrm{DDW} \quad-2 \mathrm{DFMD}=0 \quad \rightarrow 2 \mathrm{DFMD}=0,3$

Obr. 8. Varianta B.2 - výsledky citlivostní analýzy vlivu bezrozměrného koeficientu D na úroveň hladiny při průtoku $Q_{20}$

Fig. 8. Variant B.2 - results of sensitivity analysis of the influence of dimensionless coefficient $D$ on the water level at discharge $Q_{20}$ doporučeného rozmezí hodnot koeficientu D dle tab. 1. Výsledky modelu 2D (DW) vykazují naopak úrovně hladin podstatně nižší, než je tomu u 1D modelu. U modelu B se ve srovnání s prizmatickým korytem v modelu A dále neprokázala shoda ve výsledcích výpočtů pomocí modelů 2D (FM) s D = 0 a 2D (DW), tj. bez uvažování vlivu turbulence.

\section{ZÁVĚR A DISKUZE VÝSLEDKU゚}

Zohlednění vlivu turbulence při hydraulických výpočtech s použitím 2D, resp. spřažených 1D/2D numerických modelů s sebou většinou přináší zvýšenou časovou náročnost výpočtů, a to jak z hlediska podstatného prodloužení výpočetního času, tak po stránce vyšších nároků na kalibraci modelu. Provedenou citlivostní analýzou byla na modelových prípadech ověřena závislost vypočtených úrovní hladin na bezrozměrném koeficientu $D$ pro výpočet turbulentní viskozity a související prostorové diskretizaci řešené náhradní oblasti. S ohledem na rozsah provedených analýz a celkovou teoretickou náročnost řešené problematiky lze předkládaný příspěvek chápat jako úvod do daného tématu. Dosažené výsledky poskytují potenciálním uživatelům orientační představu o míre nejistot vyplývajících z prípadného zohlednění, resp. zanedbání vlivu turbulence. Za stavu, kdy jsou v praxi obvykle značně omezené zdroje odpovídajících kalibračních údajů, představuje naznačený postup citlivostní analýzy vhodný zpưsob pro získání základní predstavy o míře nejistot, kterou jsou zatíženy výsledky výpočtů. Zjištěné skutečnosti rovněž nabízejí možnosti dalšího podrobnějšího výzkumu v dané oblasti. V této souvislosti lze zmínit např. otázku nejistot souvisejících s hydraulickým řešením oblastí, kde dochází k vybřežování vody z koryta toku do přilehlého záplavového území, resp. k jejímu zpětnému nátoku např. $v$ důsledku prèévání ochranných hrází nebo překročení kapacity koryta.

\section{Poděkování}

Príspěvek vznikl za podpory projektu FAST-S-20-6305 "Nejistoty v hydraulickém posouzení transformačního účinku údolní nivy s použitím 2D a spřažených 1D/2D numerických modelü".

\section{Literatura}

[1] RODI, W. Turbulence models and their application in hydraulics: A state-of-the-art review. International Association for Hydraulic Research. CRC Press, Delft, 1993. ISBN 9789054101505.

[2] FAN, YUYAN \& AO, TIANQI \& YU, HAIJUN \& HUANG, GUORU \& LI, XIAODONG. A Coupled 1D/2D Hydrodynamic Model for Urban Flood Inundation. Advances in Meteorology, 2017. 1-12. 10.1155/2017/2819308

[3] LIU, QIANG \& QIN, YI \& ZHANG, YANG \& LI, Ziwen. A coupled 1D/2D hydrodynamic model for flood simulation in flood detention basin. Natural Hazards, 2015. 75. 10.1007/s11069-014-1373-3.

[4] PATEL, DHRUVESH \& RAMIREZ, JORGE \& SRIVASTAVA, PRASHANT \& BRAY, MICHAELA \& HAN, Dawei. Assessment of flood inundation mapping of Surat city by coupled 1D/2D hydrodynamic modelling - A case application of the new HEC-RAS 5. Natural Hazards, 2017. 10.1007/s11069-017-2956-6.

[5] PRIEUR, N. CH. Development of a 1D/2D coupled hydrodynamic model for the Øyeren Delta in southern Norway. Master Thesis in Geosciences. Department of Geosciences, University of Oslo, 2011. Blindern, Norway.

[6] VOJINOVIC, ZORAN \& TUTULIC, D. On the use of $1 D$ and coupled 1D/2D modelling approaches for assessment of flood damage in urban areas. Urban Water Journal, 2009. 6. 183-199. 10.1080/15730620802566877.

[7] PASQUIER, ULYSSE \& HE, YI \& HOOTON, SIMON \& GOULDEN, MARISA \& HISCOCK, KEVIN. An integrated $1 \mathrm{D} / 2 \mathrm{D}$ hydraulic modelling approach to assess the sensitivity of a coastal region to compound flooding hazard under climate change. Natural Hazards, 2018. 10.1007/s11069-018-3462-1.

[8] SIMON, C. A. One and two-dimensional coupling modeling approaches for flood simulations. Ph.D. Thesis. Swanson School of Engineering, University of Pittsburgh, 2019.

[9] DASALLAS, LEA \& YEONSU, KIM \& HYUNUK, An. Case Study of HEC-RAS 1D/2D Coupling Simulation: 2002 Baeksan Flood Event in Korea. Water, 2019. 11. 2048. 10.3390/w11102048. 
[10] GAETANO CRISPINO, CORRADO GISONNI \& MICHELE IERVOLINO. Flood hazard assessment: comparison of 1D and 2D hydraulic models, International Journal of River Basin Management, 2015. 13:2, 153-166, DOl: 10.1080/15715124.2014.928304

[11] ANTHI-EIRINI K. VOZINAKI, GIASEMI G. MORIANOU, DIMITRIOS D. ALEXAKIS \& IOANNIS K. Tsanis Comparing $1 \mathrm{D}$ and combined 1D/2D hydraulic simulations using high-resolution topographic data: a case study of the Koiliaris basin, Greece, Hydrological Sciences Journal, 2017. 62:4, 642-656, DOI: 10.1080/02626667.2016.1255746

[12] RABIH GHOSTINE, JOSE VAZQUEZ, ABDELALI TERFOUS, ROBERT MOSE \& ABDELLAH GHENAIM. Comparative study of $1 \mathrm{D}$ and $2 \mathrm{D}$ flow simulations at open-channel junctions, Journal of Hydraulic Research, 2012. 50:2, 164-170, DOI: 10.1080/00221686.2012.661563.

[13] RABIH GHOSTINE, IBRAHIM HOTEIT, JOSE VAZQUEZ, ABDELALI TERFOUS, ABDELLAH GHENAIM \& ROBERT MOSE Comparison between a coupled 1D/2D model and a fully $2 \mathrm{D}$ model for supercritica flow simulation in crossroads, Journal of Hydraulic Research, 2015. 53:2, 274-281, DOl:10.1080/00221686. 2014.974081.

[14] TAYEFI, V. \& LANE, STUART \& HARDY, R. \& Yu, Dapeng. A Comparison of One- and Two-Dimensiona Approaches to Modeling Flood Inundation Over Complex Upland Floodplains. Hydrological Processes, 2007. 21. 10.1002/hyp.6523.

[15] LEE, Seungsoo \& an, Hyunuk. Evaluating the Effect of Grid Size and Type in Integrated 1D/2D Coupled Urban Inundation Modeling on the Interacting Discharge between the Surface and Sewerage System. Journal of Flood Risk Management, 2019. 12. e12537. 10.1111/jfr3.12537.

[16] DASGUPTA, A. Reduction of uncertainties in a 1D/2D coupled hydrodynamic model using remote sensing data. Thesis. Faculty of Geo-Information Science and Earth Observation of the University of Twente, Netherlands, 2015.

[17] ALEXANDER Betsholtz, Beatrice Nordlöf. Potentials and limitations of 1D, 2D and coupled 1D/2D flood modelling in HEC-RAS. Master thesis. Division of Water Resources Engineering, Department of Building \& Environmental Technology, Lund University. Lund, Sweden, 2017.

[18] BRUNNER, G. W. HEC-RAS River Analysis system: Hydraulic Reference Manual. Version 5.0, Davis, California, 2016, $538 p$

[19] BRUNNER, G. W. HEC-RAS River Analysis system: Modeler Application Guidance for Steady vs Unsteady, and 1D vs 2D vs 3D Hydraulic Modeling, TD-41, Davis, California, 2020, 114 p.

[20] BRUNNER, G. W. HEC-RAS River Analysis system: Verification and Validation tests, RD-52., Davis, California, 2018, $154 \mathrm{p}$

[21] Geoportál ČÚZK [on-line]. Český úřad zeměměřický a katastrální: Státní správa zeměměřictvi a katastru, 2010, [cit. 2019-01-07]. Dostupné z: https://geoportal.cuzk.cz

[22] BRUNNER, G. W. HEC-RAS River Analysis system: User's Manual. Version 5.0, Davis, California, 2018 $960 \mathrm{p}$

\section{Autoři}

Ing. David Duchan, Ph.D.

凶duchan.d@vutbr.cz

ORCID: 0000-0003-1303-8385

Ing. Stanislav Kotaška

凶kotaska.s@fce.vutbr.cz

ORCID: 0000-0001-8907-9648

Ing. Šimon Pospíšilík

凶pospisilik.s@fce.vutbr.cz

ORCID: 0000-0001-5636-3634

Doc. Ing. Aleš Dráb, Ph.D.

凶drab.a@fce.vutbr.cz

ORCID: 0000-0002-6874-4132

Vysoké učení technické v Brně, Fakulta stavební

Příspěvek prošel lektorským řízením.
SENSITIVITY ANALYSIS OF SELECTED

INPUT PARAMETERS OF THE NUMERI-

CAL MODEL HEC-RAS IN AND FLOOD-

PLAIN FLOW CALCULATIONS

DUCHAN, D.; KOTASKA, S.; POSPISILIK, S.; DRAB, A.

Brno University of Technology, Faculty of Civil Engineering

Keywords: sensitivity analysis - hydraulic calculation -

2D numerical model - HEC-RAS - turbulence model - floodplain

In current engineering practice, hydraulic calculations of water flow in open channels and floodplains are performed primarily using 1D, 2D and coupled 1D/2D numerical models. In the case of the mentioned 2D schematization, the mathematical model is usually based on the so-called shallow water equations. In this context, the turbulence models with different concepts of turbulence modeling are used to mathematically describe turbulent flow. At present, the HEC-RAS software, which uses a turbulence model based on the Boussinesq approximation, is relatively widespread for the purposes of hydraulic calculations. The aim of the paper is to present the results of sensitivity analysis taking into account the influence of the input parameters of the turbulence model on the results of hydraulic calculations in the case of using 2D schematization or in the use of coupled 1D/2D model. The analyzes also include verification of the possible influence of the results by changes in other parameters of the calculation, which include, for example, the use of diffusion wave approximation or the method of spatial discretization of the solved region. For verification calculations, a fictitious reach with a trapezoidal cross-section was selected, as well as a real section of the Svratka river in the city of Brno in the length of approximately $2.6 \mathrm{~km}$. The purpose of this paper is to provide a basic idea of the uncertainties arising from the choice of selected input parameters for potential users of 2D numerical models.

DOI: 10.46555/VTEI.2021.01.001 